\title{
KOMUNIKASI TERAPEUTIK ISLAMI DALAM PELAYANAN KESEHATAN PASIEN DI RUMAH SAKIT AL HUDA GENTENG
}

\author{
Nur Hafifah \\ Program Studi Komunikasi dan Penyiaran Islam \\ Institut Agama Islam Negeri Jember
}

Diunggah 06 Oktober / Direvisi 22 Oktober / Diterima 16 November 2019

\begin{abstract}
Abstrac: This study aims to know the forms of therapeutic communication conducted by doctors and paramedics in Patient Health Services, especially toward patients in one of the Islamic hospitals in Banyuwangi, namely Al Huda GentengBanyuwangi. This study also signifies the application of communication therapeutic performed by doctors and paramedics on patients in order to provide the best health services and find an overview of the patient's response to the application of therapeutic communication applied with the principles of Islamic Communication. The theoretical framework used in this study is the Interpersonal Communication Theory proposed by Joseph A. Devito, Therapeutic Communication Theory initiated by Hildegard Peplau, and also the Theory and principles of Islamic Communication based on the Al Qur'an. This study uses a qualitative descriptive approach. The technique of data collection is observation, in-depth interviews, literature studies, and documentation. The Informants in this study were doctors and paramedics as communicators in the process of therapeutic communication and patients as communicants or recipients of therapeutic communication services. The data is processed using the Miles and Huberman models, namely through three steps, the first is data reduction, the second step is presenting the data, and the last stage is the conclusion. The results of the research revealed that forms of therapeutic communication carried out by doctors and paramedics/ nurses towards patients in the orientation phase, working phase and phase of termination were through interpersonal communication with the delivery of messages through forms of verbal communication, written communication, and nonverbal communication. The form of verbal communication is implemented through clear and concise dimensions, vocabulary, pauses and speaking opportunities, the meaning of denotative and connotative appropriate time, and also relevance humor. The form of written communication is carried out through letters, memos, prescription drugs with attention to clarity and accuracy of messages, and forms of nonverbal communication carried out through selfappearance, tone of voice, facial expressions, and touch. All forms and dimensions of interpersonal communication have not been applied and provided by doctors and paramedics/nurses, as well as the principles of Islamic communication which have not implemented optimally. It also does not become a guideline in providing health services to patients in Islamic hospitals in Genteng Banyuwangi yet.
\end{abstract}

Keywords; Islamic Therapeutic Communication, Patient Health Services.

Korespondensi: Nur Hafifah

Pascasarjana IAI Jember 


\section{A. PENDAHULUAN}

Komunikasi merupakan interaksi antarpribadi yang menggunakan sistem simbol linguistik, seperti sistem verbal (kata-kata) dan non verbal. Sistem ini dapat disosialisasikan secara langsung/ tatap muka atau melalui media lain (tulisan, oral dan visual).

Menurut Carl.I.Hovland dalam Widjaja mengatakan bahwa komunikasi adalah suatu proses dimana seseorang memindahkan perasaannya yang biasanya berupa lambang-lambang atau kata-kata untuk mengubah tingkah laku orang lain. ${ }^{1}$

Tujuan dari proses komunikasi yaitu perubahan berupa penambahan pengetahuan, merubah pendapat, memperkuat pendapat serta merubah siikap dan perilaku komunikan yaitu : perubahan pada pikiran (kognitif), perubahan pada perasaan (afektif) dan perubahan pada perilaku (behavior).

Karena begitu pentingnya komunikasi, maka komunikasi dapat juga dijadikan alat terapi /metode terapi pada profesi tertentu, yang dalam menjalankan tugasnya sering berhubungan dengan orang lain. ${ }^{2}$ Komunikasi yang dilakukan dokter dan paramedis/perawat dapat berfungsi sebagai alat terapi yang kemudian disebut "komunikasi terapeutik".

Komunikasi terapeutik adalah komunikasi langsung yang dilakukan dokter dan paramedis/perawat terhadap pasien untuk mengetahui keadaan dan tanggapan pasien saat diperiksa, demikian juga pasien mengetahui perhatian yang diberikan oleh dokter dan tenaga paramedik. ${ }^{3}$

Rogers dalam bahwa inti dari hubungan antar pribadi dalam komunikasi terapeutik adalah kehangatan, ketulusan, pemahaman yang empatik serta perhatian positif. ${ }^{4}$

Dalam perpektif ilmu komunikasi terapeutik, dokter dan paramedis dapat memberikan pelayanan komunikasi terhadap pasien melalui pendekatan komunikasi verbal, yaitu pemberian pesan yang jelas dan ringkas, perbendaharaan kata, pemaknaan denotatif dan konotatif, kesempatan berbicara, penggunaan waktu dan relevansi serta pemberian humor. Disamping komunikasi verbal, komunikasi tertulis juga dilakukan untuk kelancaran komunikasi terapeutik, seperti penulisan nama obat

\footnotetext{
${ }_{1}^{1}$ Widjaja, HAW., Ilmu Komunikasi : Pengantar Studi. (Jakarta; Rineka Cipta, 2000), 15

2 Wijaya Dkk, Komunikasi Terapeutik, (Jakarta: Akademi Kesehatan Gigi Depkes RI, 1996), 20

3 Wijaya Dkk, Komunikasi Terapeutik, (Jakarta: Akademi Kesehatan Gigi Depkes RI, 1996), 34

${ }^{4}$ Arwani, Komunikasi Dalam Keperawatan. (Jakarta:Buku Kedokteran EGC, 1999), 15
} 
atau resep obat yang diberikan dokter, memo atau penulisan surat keterangan tentang penyakit, dokumen medis pasien dsb. Komunikasi non verbal juga digunakan dalam interaksi antara dokter dan paramedis/perawat terhadap pasien, antara lain penampilan diri (self performance), intonasi suara (voive tone), ekspresi wajah, dan sentuhan yang tulus (haptik) sehingga pasien merasa tenang, senang dan nyaman selama menjalani proses penyembuhan.

Teoritikus keperawatan paling awal yang mengeksplorasi hubungan dokter, perawat dan pasien dan komunikasi keperawatan adalah Hildegard Peplau mengembangkan Teori Hubungan Interpersonal yang menekankan timbal balik (resiprositas) di dalam hubungan interpersonal antara perawat dan pasien. ${ }^{5}$ Teori Peplau menggerakkan pemikiran mengenai keperawatan dari apa yang perawat lakukan kepada pasien menjadi apa yang perawat lakukan dengan pasien, membuat hubungan keperawatan menịadi proses interaktif dan kolaboratif antara perawat dan pasien. Terdapat 3 (tiga) fase komunikasi terapeutik yang dilakukan dokter dan paramedis terhadap pasien yakni :

Fase Perkenalan (Orientation) dilaksanakan setiap kali pertemuan dengan pasien, kemudian fase Kerja (Working) merupakan inti dari keseluruhan proses komunikasi terapeutik, dan selanjutnya fase akhir pertemuan (Termination) merupakan akhir dari pertemuan dokter dan paramedis/perawat dengan pasien.

Dalam perspektif Islam, yang dimaksud komunikasi yang benar adalah komunikasi yang Islami, yaitu komunikasi yang berakhlak al karimah atau beretika yang berarti komunikasi yang bersumber kepada Al Quran dan hadis (sunnah Nabi). Menurut A. Muis, komunikasi Islami memiliki perbedaan dengan komunikasi yang non Islami. Perbedaan itu lebih pada isi pesan (content) komunikasi yang harus terikat perintah agama, dan dengan sendirinya pula unsur isi pesan mengikat pada unsur komunikator. ${ }^{6}$ Artinya, komunikator harus memiliki dan menjunjung tinggi prinsip etika Islam dalam menyampaikan pesan ketika berbicara.

Ada enam prinsip komunikasi Islam yang menjadi pedoman dalam berkomunikasi yaitu: Pertama, prinsip Qoulan Sadida, artinya pembicaraan yang benar, dan jujur, bersifat straight to the point, lurus, tidak bohong dan tidak berbelitbelit. Kedua, prinsip Qoulan Baligha, artinya jelas maknanya, terang, tepat

\footnotetext{
${ }^{5}$ Lisa Kennedy Sheldon, Komunikasi Untuk Keperawatan, (Surabaya; Erlangga, 2010), 56

${ }^{6}$ Muis, A., Komunikasi Islami (Bandung: Remaja Rosda Karya, 2001), 31
} 
mengungkapkan apa yang dikehendaki, komunikasi yang efektif. Ketiga, prisip Qoulan Ma'rufa, artinya perkataan yang baik, perkataan yang menimbulkan rasa tentram dan damai bagi orang yang mendengarkannya. Keempat,prinsip Qoulan Karima, artinya perkataan yang diucapkan adalah perkataan yang baik, enak didengar dan manis dirasakan, yang mencerminkan kemuliaan. Kelima, prinsip Qoulan Layyina, artinya pembicaraan yang lemah lembut agar pesan yang disampaikan lebih dapat menyentuh hati dan diterima sebagai pesan yang menarik. Keenam, prinsip Qoulan Maysura, artinya tuntunan untuk melakukan komunikasi dengan bahasa yang mudah dimengerti dan melegakan perasaan mudah dicerna dalam pikiran dan perasaan. ${ }^{7}$

Perkembangan beberapa rumah sakit bernuansa Islami di Banyuwangi membuat masyarakat memiliki banyak pilihan untuk menentukan rumah sakit yang akan mereka pilih.Salah satu rumah sakit bernuansa Islami di Banyuwangi ini adalah rumah sakit Al Huda Genteng. Pada Rumah sakit bernuansa Islami konsep pelayanankomunikasinya diasumsikan berbasis prinsip-prinsip komunikasi Islam yang berpedoman pada Al Qur'an dan Hadits.

Namun demikian dalam hubungannya dengan kepuasan pasien dalam pelayanan kesehatan di rumah sakit Al Huda Genteng, sebagai sebuah rumah sakit yang bernuansa Islami masih ada beberapa persepsi yang kurang baik dan keluhan pasien terutama dalam hal komunikasi terapeutik yang dilakukan oleh Dokter dan Paramedis/perawat dalam asuhan medis dan asuhan keperawatan. Beberapa konflik terjadi akibat dari komunikasi yang tidak jelas atau tidak komunikatif sehingga menimbulkan kekecewaan dan ketidakpuasan serta kepercayaan yang rendah dari pasien.

\section{B. PEMBAHASAN}

\section{Komunikasi Terapeutik Islami}

Komunikasi interpersonal seperti diungkapkan Devito adalah prose pengiriman dan penerimaan pesan antara dua orang atau diantara sekelompok kecil orang dengan beberapa efek dan umpan balik seketika dan merupakan suatu

\footnotetext{
7 Ujang Saefullah, Kapita Selekta Komunikasi Pendekatan Budaya dan Agama, (Bandung: Simbiosa Rekatama Media, 2007),63
} 
proses pertukaran makna antara orang-orang yang saling berkomunikasi. ${ }^{8}$ Komunikasi interpersonal menurut Devito dinilai paling baik dalam kegiatan mengubah sikap, kepercayaan, opini, dan perilaku komunikan

Komunikasi antara dokter dan paramedis terhadap pasien dalam pelayanan kesehatan di rumah sakit adalah salah satu contoh dari kegiatan komunikasi interpersonal. Sebagaimana menurut Purwanto yang mengatakan: "Komunikasi terapeutik termasuk komunikasi interpersonal dengan titik tolak saling memberikan pengertian antara dokter, paramedis dan pasien. ${ }^{9}$

Persoalan mendasar dari komunikasi terapeutik sebagai komunikasi interpersonal adalah terdapatnya hubungan interpersonal yang terịalin dan kondisi yang saling membutuhkan antara dokter, paramedis/perawat terhadap pasien dalam pelayanan kesehatan di rumah sakit.

Menurut Purwanto komunikasi terapeutik adalah komunikasi yang dilakukan atau dirancang untuk tuj̣uan terapi, direncanakan secara profesional, sadar, bertujuan dan dipusatkan untuk kesembuhan pasien. ${ }^{10}$

\section{Prinsip Dasar Komunikasi Terapeutik.}

Komunikasi terapeutik dilakukan untuk meningkatkan pemahaman dan membantu terbentuknya hubungan yang konstruktif diantara dokter, perawat dan pasien.Prinsip dasar komunikasi terapeutik sebagai berikut:

a. Hubungan dokter, perawat dan pasien adalah hubungan terapeutik yang saling menguntungkan, didasarkan pada prinsip 'humanity of nurses and clients'.Hubungan ini tidak hanya sekedar hubungan seorang penolong (helper/ dokter dan perawat) dengan pasiennya, tetapi hubungan antara manusia yang bermartabat, menurut Dult-Battey. ${ }^{11}$

b. Dokter dan paramedis/perawat harus menghargai keunikan pasien, perbedaan karakter, memahami perasaan dan perilaku pasien dengan melihat perbedaan latar belakang keluarga, budaya, dan keunikan pasien sebagai individu.

c. Semua komunikasi yang dilakukan harus dapat menịaga harga diri pemberi

\footnotetext{
8 Joseph A Devito, Komunikasi Antar Manusia. Terjemahan Agus Maulana. (Jakarta: Profesional Books, 1997), 23

${ }^{9}$ Hery Purwanto, Komunikasi Untuk Perawat. (Jakarta: EGC, 1994), 67

${ }^{10}$ Hery Purwanto, Komunikasi Untuk Perawat. (Jakarta: EGC, 1994), 23

11 Agus Priyanto, Komunikasi dan Konseling Aplikasi Dalam Sarana Pelayanan Kesehatan Untuk Perawat dan Bidan, (Jakarta: Salemba Medika, 2009), 56
} 
maupun penerima pesan,

d. Komunikasi yang menciptakan tumbuhnya hubungan saling percaya (trust) harus dicapai terlebih dahulu sebelum menggali permasalahan dan memberikan alternatif pemecahan masalah. Hubungan saling percaya antara dokter dan paramedis atau perawat terhadap pasien adala kuncidarikomunikasiterapeutik.

\section{Bentuk-bentuk Komunikasi Terapeutik}

a. KomunikasiVerbal

Jenis komunikasi yang paling lazim digunakan dalam pelayanan kesehatan di rumah sakit adalah pertukaran informasi secara verbal dengan tatap muka. Komunikasi verbal lebih akurat dan tepat waktu. Kata- kata adalah alat atau simbol yang dipakai untuk mengekspresikan ide \&perasaan, membangkitkan respon emosional,, menguraikan obyek, observasi dan ingatan seseorang. Beberapa hal yang harus diperhatikan dalam melakukan komunikasi verbal yang efektif seperti ;

1) Jelas dan ringkas, sederhana, pendek dan langsung.

2) Perbendaharaankata (mudah dipahami)..

3) Arti denotatif dan konotatif. Memberikan pengertian yang sama terhadap kata yang digunakan, dan merupakan pikiran, perasaan /ide yang terdapat dalam suatu kata.

4) Jeda (Selaan) dan kesempatan berbicara,

5) Waktu dan Relevansi yang tepat

6) Humor, Dugan dalam Rakhmat mengatakan bahwa tertawa membantu pengurangi ketegangan dan rasa sakit yang disebabkan oleh ormone, dan meningkatkan keberhasilan perawat dalam memberikan dukungan emosional terhadap pasien. ${ }^{12}$

b. Komunikasi Tertulis

Merupakan satu bentuk komunikasi yang digunakan dalam layanan komunikasi terapeutik dokter dan paramedis terhadap pasien seperti penulisan nama obat, memo atau penulisan surat, keterangan tentang penyakit, keterangan harga obat, dll.Komunikasi lewat tulisan harus ; lengkap,

12 Jalaluddin Rakhmat, Psikologi Komunikasi. (Bandung: Penerbit PT. Remaja Rosda Karya, 2001), 286 
ringkas, kongkrit, jelas, sopan,dan benar. Fungsi komunikasi tertulis dalam komunikasi terapeutik di rumah sakit antara lain sebagai berikut :

1) Sebagai tanda bukti tertulis yang otentik, .

2) Alat pengingat/berpikir bilamana diperlukan,

3) Dokumentasi historis,.

4) Jaminan keamanan,.

5) Pedoman atau dasar bertindak,

c. Komunikasi Nonverbal

Komunikasi Nonverbal adalah komunikasi yang pesannya dikemas dalam bentuk nonverbal tanpa kata-kata. Morris dan Liliweri membagi pesan non verbal sebagai berikut: ${ }^{13}$

1) Kinesik,

2) Proksemik,

3) Paralinguistik,

4) Haptik

5) Artefak

6) Logo dan Warna,kreasi dan perancang.

7) Tampilan Fisik Tubuh.

Priyanto melengkapi bentuk-bentuk komunikasi non verbal sebagai berikut: ${ }^{14}$

1) Penampilan Individu

2) b)Intonasi Suara

3) c). Ekspresi Waịah

4) d). Sentuhan

\section{Fase atau Tahapan Dalam Komunikasi Terapeutik}

Terdapat tiga tahapan/ fase komunikasi terapeutik menurut Hildegard Peplau yakni: 15

a. Fase Orientasi, tahap perkenalan, bertuịuan untuk melakukan validasi keakuratan data pasien dan rencana yang telah dibuat sesuai dengan keadaan

\footnotetext{
${ }^{13}$ Jalaluddin Rakhmat, Psikologi Komunikasi. (Bandung: Penerbit PT. Remaja Rosda Karya, 2001), 295

${ }^{14}$ Agus Priyanto, Komunikasi dan Konseling Aplikasi Dalam Sarana Pelayanan Kesehatan Untuk Perawat dan Bidan, (Jakarta: Salemba Medika, 2009), 16

${ }^{15}$ Lisa Kennedy Sheldon, Komunikasi Untuk Keperawatan, (Surabaya; Erlangga, 2010), 56
} 
klien saat terkini, mengevaluasi hasil tindakan yang lalu atau tindakan sebelumnya. Lima kegiatan pokok fase ini yaitu testing (percobaan untuk saling berkenalan) building trust (membangun kepercayaan), identification of problems and goals (identifikasi permasalahan, menetapkan tujuan), clarification of roles (mengklarifikasi peran) dan contract formation (membuat perịanịian atau kontrak perawatan).

b. Fase Kerịa (Working) merupakan inti dari keseluruhan proses komunikasi terapeutik, tahap terpanịang dalam komunikasi terapeutik karena didalamnya dokter dan paramedis diwajibkan untuk membantu pasien menyampaikan perasaan dan pikirannya, menganalisa respons, pesan komunikasi verbal dan non verbal yang disampaikan oleh pasien, terdiri dari dua kegiatan pokok yaitu menyatukan proses komunikasi dengan tindakan perawatan dan membangun suasana yang mendukung untuk proses perubahan.

c. Fase Terminasi / akhir pertemuan, dibagi dua yaitu terminasi sementara ,yaitu akhir dari tiap pertemuan perawat dan pasien dan terminasi akhir , dilakukan oleh perawat setelah menyelesaikan seluruh proses keperawatan. tujuan telah dicapai, Kegiatan pada fase ini adalah penilaian pencapaian tujuan dan perpisahan.

\section{Komunikasi Terapeutik Dalam Perspektif Islam}

Komunikasi Islam adalah proses penyampaian pesan-pesan keIslaman dengan menggunakan prinsip-prinsip komunikasi Islami. Dengan pengertian demikian, maka komunikasi Islam menekankan pada unsur-unsur komunikasi, termasuk dalam penyampaian pesan (message) yang berisi risalah atau nilai-nilai Islam dan cara penyampaian (how to communicate) yaitu tentang gaya pembicaraan dan pemilihan serta penggunaan bahasa. Pesan-pesan keIslaman yang disampaikan dalam komunikasi Islam meliputi seluruh ajaran Islam yang terdiri dari akidah (iman), syariah, dan akhlak (ihsan).

\section{Konsep Dasar Komunikasi Islam}

Menurut Harjani Hefni, konsep dasar dalam komunikasi Islam yaitu: ${ }^{16}$

a. Komunikasi Ada Sejak Manusia Ada.

16 Hardjani Hefni, Komunikasi Islam, (Jakarta: Prenadamedia Group, 2015), 5 
b. Komunikasi terkait dengan pandangan Islam terhadap manusia,yaitu sebagai makhluk empat dimensi, sebagai makhluk Allah, sebagai diri sendiri, sebagai makhluk yang hidup dengan sesama dan sebagai makhluk yang hidup di alam semesta.

c. Komunikasi adalah kebutuhan dasar manusia

d. Komunikasi adalah wujud dari kasih sayang Allah terhadap manusia

e. Komunikasi bertujuan untuk saling mengenal antar manusia buat mewuịudkan semangat taqwa.:

f. Komunikasi bertujuan untuk menebar semangat slim (kedamaian dan kenyamanan)

g. Komunikasi adalah paket pesan yang diucapkan oleh lisan atau yang digoreskan oleh pena atau yang diisyaratkan oleh anggota tubuh merupakan terịemahan dari keinginan hati

h. Komunikasi memiliki efek dunia dan ahirat.

i. Menurut Syukur Kholil menjelaskan setidaknya terdapat 11 prinsip komunikasi Islam sebagai berikut: ${ }^{17}$

j. Memulai pembicaraan(komunikasi) dengan mengucapkan salam

k. Berbicara dengan lemah lembut

l. Menggunakan perkataan yang baik

m. Menyebutkan hal-hal yang baik tentang diri komunikan

n. Menggunakan hikmah dan nasehat yang baik

o. Berlaku adil

p. Menyesuaikan bahasa dan isi pembicaraan dengan keadaan komuniukan

q. Berdiskusi dengan cara yang baik

r. Lebih dahulu mengatakan apa yang dikomunikasikan

s. Mempertimbangkan pandangan dan fikiran orang lain

t. Berdoa kepada Allah SWT ketika melakukan kegiatan komunikasi yang berat.

Al-Qur'an tidak membicarakan secara spesifik tentang komunikasi, namun ada makna-makna yang terkandung dalam Al -Qur'an yang memberikan gambaran umum tentang prinsip-prinsip komunikasi. key concept yang dipergunakan Al-Qur'an untuk berkomunikasi adalah al-qaul. Setidaknya ada 6

${ }^{17}$ Syukur Kholil, Komunikasi Islami, (Bandung: Cita Pustaka Media, 2007) 
j̣enis gaya bicara sebagai kaidah, etika dan prinsip-prinsip komunikasi Islami, yakni :

1) Qaulan Sadida, dalam QS Al Ahzab ,80., QS Al Haịi ,30 dan Hadits riwayat Muttafaq Alaih.Qaulan Sadida berarti pembicaraan, ucapan atau perkataan yang benar, baik dari segi substansi (materi, isi pesan) maupun redaksi (tata bahasa).

2) Qaulan Baligha, dalam QS An Nisaa 63, dan Hadits riwayat Muslim. berarti tepat, lugas, fasih dan jelas maknanya. menggunakan kata-kata yang efektif, tepat sasaran, komunikatif , mudah dimengerti, langsung ke pokok masalah (straight to the point), dan tidak berbelit- belit atau bertele-tele.

3) Qaulan Ma'rufa, dalam QS An Nissa ayat 5,Qaulan Ma'rufa artinya perkataan yang baik, ungkapan yang pantas, santun, menggunakan sindiran (yang tidak kasar] dan tidak menyakitkan ataumenyinggung perasaan, pembicaraan yang bermanfaat dan menimbulkan kebaikan (nasehat yang baik).

4) Qaulan Karima, dalam QS Al Isra 23. Qaulan Karima adalah perkataan yang mulia, dibarengi dengan rasa humor dan mengagungkan, enak didengar, lemah-lembut, dan bertatakrama.

5) Qaulan Layyin, dalam QS Thaha ayat 44 yang artinya : Maka berbicaralah kamu kepadanya dengan kata-kata yang lemah lembut qaulan layyina, mudahmudahan ian ingat atau takut”. (Q.S. Thaha ; 44)Qaulan Layyina berarti pembicaraan yang lemah lembut dengan suara yang enak didengar, dan penuh keramahan, sehingga dapat menyentuh hati.

6) Qaulan Masyura. Qaulan Maysura di dalam QS Al Isra ayat 28 . yang artinya mudah atau gampang. Ketika kata maysura digabungkan dengan kata qaulan menịadi Qaulan Maysura yang artinya berkata dengan mudah dicerna, gampang dimengerti

\section{Prinsip-prinsip Komunikasi Islam dalam Komunikasi Terapeutik}

Komunikasi terapeutik merupakan hubungan interpersonal dan merupakan interaksi bersama dokter, paramedis/perawat dengan pasien yang dilakukan secara terencana dan bertujuan untuk menyelesaikan masalah yang dihadapi pasien, memperbaiki emosi pasien dan berfokus pada kesembuhan pasien.

Pasien adalah seseorang yang sedang membutuhkan pertolongan karena 
keadaan sakit yang dideritanya. Dalam keadaan sakit, seseorang selain mengeluhkan penderitaan fisiknya, biasanya j̣uga disertai dengan gangguan dan guncangan j̣iwa dengan gej̣ala seperti cemas, takut, kehilangan harapan, putus asa, emosi labil dan lainnya. Hal ini waj̣ar, karena secara fisik seseorang yang sedang sakit akan dihadapkan pada tiga alternatif kemungkinan yang akan dialaminya yaitu : sembuh sempurna, sembuh disertai cacat sehingga terdapat kemunduran pada fungsi organ-organ tubuhnya, atau meninggal dunia. Kecemasan dan ketakutan seperti ini dapat menyebabkan timbulnya stres psikis yang j̣ustru akan melemahkan respon imunologi (daya tahan tubuh) dan mempersulit proses penyembuhan diri. Menghadapi kondisi ini bimbingan rohani sangat diperlukan agar j̣iwa pasien tidak terguncang, sehingga ia dapat menjadi lebih kuat, yang pada akhirnya akan membantu proses kesembuhan.

Gangguan psikis yang dialami oleh orang yang sedang sakit dapat berakibat pada lemahnya iman seseorang. Karena tipisnya keimanan atau akidah, kemudian muncul rasa putus asa, sampai keinginan untuk mengahiri hidupnya dengan j̣alan yang tidak diridhai Allah SWT, sehingga terkadang ada pasien yang sengaịa meninggalkan ibadah sehari-hari seperti sholat,berdoa,dzikir dll.Akibatnya kondisi psikis dan keimanan nurani orang tersebut semakin gersang.

Dalam pandangan Islam , penyakit merupakan cobaan yang diberikan Allah SWT kepada hambaNya untuk menguj̣i keimanannya. Melalui komunikasi terapeutik, dokter dan paramedis/perawat dapat meyakinkan kepada pasien bahwa pemahaman dan persepsi yang keliru tentang takdir bisa mengakibatkan sikap anti usaha dan tidak semangat terhadap upaya-upaya produktif. Komunikasi terapeutik yang dilakukan seorang dokter dan paramedis/perawat dengan bekal rohani dan nilai keIslaman yang mumpuni dapat berperan. Tujuannya menolong pasien dan memperbaiki problem emosinya dalam rangka menuju kesembuhan. Komunikasi terapetik dengan menerapkan prinsip-prinsip komunikasi Islam dapat menjadi pedoman utama bagi dokter dan paramedis/pasien yang sedang melakukan komunikasi terapeutik guna memperoleh komunikasi efektif dalam rangka mencapai tuj̣uan utama dari komunikasi terapeutik yaitu menolong pasien.

Pada akhirnya komunikasi terapeutik yang menerapkan prinsip-prinsip komunikasi Islam didalam proses nya, akan mudah menjalin hubungan rasa 
percaya dengan pasien,dapat mencegah terịadinya masalah legal, memberikan kepuasan profesional dalam pelayanan medis dan pelayanan keperawatan,dan dapat meningkatkan citra profesi medis dan citra profesi keperawatan serta citra rumah sakit. Dan yang lebih penting adalah mengamalkan ilmunya untuk memberikan pertolongan terhadap sesama manusia.

\section{Pelayanan Kesehatan di Rumah Sakit Bernuasa Islami}

Setiap pengelolaan selalu berupaya untuk memberikan dan meningkatkan kualitas pelayanan terbaik sesuai dengan tuntutan konsumen pengguna barang maupun j̣asa. Pelayanan didefinisikan Lovelock sebagai kegiatan ekonomi yang menciptakan dan memberi manfaat bagi pelanggan pada waktu dan tempat tertentu. ${ }^{18}$ Menurut Kotler, setiap kegiatan yang dapat ditawarkan oleh satu pihak kepada pihak lain yang pada dasarnya tidak berwujud dan tidak mengakibatkan kepemilikan apapun. ${ }^{19}$

Pelayanan merupakan bagian dari komunikasi karena terdapat dimensi etika dan prinsip komunikasi pada saat proses pelayanan berlangsung, berupa tempat dan waktu, nilai, kebudayaan, cara hidup, cara berinteraksi yang digunakan dalam setiap ruang lingkup baik ekonomi, sosial, politik dsb.Menurut Parasuraman dan Leonard L. Berry ada 5 dimensi dalam pelayanan untuk dapat memberi kepuasan pelanggan yaitu: ${ }^{20}$
a. Tangibles (bukti fisik).
b. Reliability (kehandalan)
c. Responsiveness (ketanggapan)
d. Assurance (jaminan dan kepastian)
e. Emphaty (empati) .

Rumah sakit sebagai bagian dari sistem kesehatan nasional dituntut untuk meningkatkan kualitas penyediaan fasilitas, pelayanan dan kemandirian. Faktor manusia sebagai pemberi pelayanan terhadap pasien dalam sebuah rumah sakit dianggap sangat menentukan dalam menghasilkan pelayanan yang berkualitas. Menurut Thoha "kualitas pelayanan pada masyarakat sangat tergantung pada

\footnotetext{
18 Fandy Tjiptono, Manajemen Jasa, (Jakarta: Andi Press, 1995), 25

19 Philip Kotler, Marketing Management, $11^{\text {th }}$ (New Jersey: Prentice Hall,Inc. 2003), 85

20 Philip Kotler, Marketing Management, $11^{\text {th }}$ (New Jersey: Prentice Hall,Inc. 2003), 85
} 
individual aktor dan sistem yang dipakai". ${ }^{21}$ Dokter, paramedis/perawat, dan tenaga penunịang medis serta non medis yang bertugas di rumah sakit harus memahami cara Kemampuan rumah sakit dalam memenuhi kebutuhan pasien dapat diukur dari tingkat kepuasan pasien. Kepuasan pasien dapat membentuk persepsi dan selanịutnya dapat memposisikan produk rumah sakit tersebut.

Dalam perspektif Islam kegiatan pelayanan medis dan pelayanan keperawatan merupakan manifestasi dari fungsi manusia sebagai khalifah Allah dalam melaksanakankemanusiaannya, Permasalahan pasien dengan segala keunikannya tersebut harus dihadapi dengan pendekatan silaturrahmi (interpersonal) dengan sebaik-baiknya didasari dengan iman, ilmu dan amal. Untuk itu Dokter dan paramedis/perawat dituntut memiliki ketrampilan intelektual, interpersonal, teknikal serta memiliki kemampuan berdakwah amar ma'ruf nahi mungkar.

Menurut Rusdi Lamsudin dalam melaksanakan pelayanan kesehatan profesional yang Islami harus berpedoman pada kaidah-kaidah Islam, medis dan keperawatan yang mencakup: ${ }^{22}$

a. Menerapkan konsep, teori, dan prinsip dalam keilmuan yang terkait dengan asuhan medis dan asuhan keperawatan dengan mengutamakan berpedoman pada Al-Qur'an dan Hadits.

b. Melaksanakan asuhan medis dan asuhan keperawatan dengan menggunakan pendekatan Islami melalui kegiatan-kegiatan pengkaj̣ian yang berdasar bukti (evidence-based healthcare).

c. Mempertanggungiawabkan atas segala tindakan dan perbuatan yang berdasarkan bukti (evidence-based halthcare)

d. Berlaku ịujur, ikhlas dalam memberikan pertolongan kepada pasien dan semata-mata mengharap ridho Allah.

e. Bekerịasama dengan tenaga kesehatan lainnya untuk meningkatkan mutu pelayanan kesehatan dan menyelesaikan masalah pelayanan kesehatan yang berorientasi pada asuhan medis dan asuhan keperawatan yang berdasarkan bukti (evidence-based helthcare).

${ }^{21}$ Thoha, Perilaku Organisasi, (Jakarta: Raja Grafindo Persada, 2002), 181

22 Rusdi Lamsudin, Nuansa Pelayanan Kesehatan yang Islami di Rumah Sakit Islam, (Yogyakarta : Suara Muhammadiyah, 2002), 3 , 


\section{SDM yang terlibat dalam Pelayanan Kesehatan yang Islami}

Sebagai hamba Allah para dokter dan paramedis/perawat yang bekerịa di rumah sakit yang bernuansa Islami memiliki tujuan hidup Fid-dunia Hasanah dan Fil-akhirah Hasanah. Ia semata-mata mengabdi kepada Allah (QS Al-An'am, 112) dengan cara mematuhi semua perintah Allah dan menịauhi semua larangan Allah, Rasul-Nya dan Ulil Amri. Dokter dan paramedis muslim harus menyadari dan menginsyafi bahwa mengobati orang sakit karena Allah, adalah suatu amal yang mulia nilainya,mereka adalah khalifah Allah dalam bidang kesehatan.

Dalam melaksanakan pelayanan kesehatan yang Islami di rumah sakit, para dokter dan paramedis muslim haruslah mencerminkan pada pengetahuan, sikap dan ketrampilan yang profesional. Secara khusus, sifat-sifat yang harus dimiliki oleh dokter dan paramedis/perawat muslim dalam melaksanakan pelayanan kesehatan ,menurut aịaran Islam antara lain : Tulus karena Allah ( QS Al Bayyinah ,5), Penyantun (QS Al A'raf, 56 dan QS Al Baqoroh ,263), Ramah (QQS Ali Imran, 159), Sabar (Asy-Syura, 43), Tenang (Hadits riwayat Ibnu Sa'ad), Tegas (Hadits riwayat Ahmad dan Bukhori), Patuh pada peraturan (Hadits riwayat Bukhori, Muslim dan Abu Daud), Bersih (At-Taubah, 108, Al- Muddattsir, 4, Hadits riwayat Abu Daud), Penyimpan rahasia (QS An-Nisa, 148, An-Nur, 19, Hadits riwayat Ibnu Maịiah,Abu Daud, Muslim, Abu Hurairah), Dapat dipercaya (QS Al-Mukminun,111, Al- Anfal, 27. An-Nisa, 58, Hadis riwayat Ahmad), Bertanggungịawab (QS Al Isra',36, Hadits riwayat Ibnu Hibban, Anas bin Malik dan Ahmad).

\section{0rganisasi Manajemen Rumah Sakit yang Islami}

Secara umum organisasi manajemen rumah sakit yang Islami mencakup kegiatan antara lain : menerapkan teori manajemen dan kepemimpinan berdasarkan kaidah-kaidah Islam, melakukan fungsi manajemen (perencanaan, pengorganisasian, pengarahan dan pengawasan) dengan berpedoman kepada syariah Islam serta menerapkan akhlakul karimah, pimpinan rumah sakit bertindak sebagai ulama dan umara untuk meningkatkan motivasi dan kinerja pelayanan kesehatan, pimpinan rumah sakit menjadi contoh yang baik (uswatun hasanah) dalam berperan sebagai tenaga medis dan paramedis profesional Islam.

\section{Lingkungan Rumah Sakit yang Islami}

Lingkungan yang Islami di sebuah rumah sakit tentu akan terlihat dengan adanya suasana keagamaan, (ada masjid, shalat jamaah, hiasan-hiasan dinding 
yang ada kaitannya dengan kesehatan dan Islam), kenyamanan, kebersihan, ketenangan, kesejukan, ketertiban, disiplin, mudah mendapatkan informasi, cepat mendapatkan pelayanan dan keramah-tamahan seluruh karyawan yang bekerja di rumah sakit, yang semuanya itu merupakanpengejawantahan dari nilai-nilai dan ajaran Islam dalam bidang pelayanan kesehatan.

Komunikasi terapeutik dokter dan paramedis/perawat kepada pasien di rumah sakit adalah proses tahapan komunikasi interpersonal yang sangat penting dalam pelayanan kesehatan di rumah sakit.

Kualitas komunikasi yang terjalin dengan baik dan efektif pada setiap fase atau tahapan komunikasi yang terjadi antara kedua belah pihak (antara dokter,paramedis/perawat kepada pasien, dan sebaliknya) akan menghasilkan kepuasan dalam diri pasien dalam upaya mendapatkan kesembuhan.

Sebagaimana pendapat Keltner, Schwecke dan Bostrom dalam Potter dan Perry yang berpendapat bahwa komunikasi terapeutik adalah proses dimana dokter dan perawat menggunakan pendekatan terencana dalam mempelajari pasiennya. ${ }^{23}$ Komunikasi terapeutik merupakan suatu interaksi interpersonal antara dokter dan paramedis/perawat dan pasien. Selama komunikasi berlangsung, dokter dan paramedis/perawat berfokus pada kebutuhan pasien untuk meningkatkan pertukaran informasi yang efektif.

Untuk mewujudkan hubungan interpersonal yang baik dan mendukung kepuasan pasien dalam menerima layanan kesehatan yang optimal dan berkualitas prima di rumah sakit yang bernuansa Islami, Dokter dan paramedis/perawat sebagai komunikator yang menyampaikan pesan atau informasi kepada pasien sebagai komunikan, perlu meningkatkan kemampuan komunikasi interpersonalnya melalui pemahaman dan penerapan prinsip-prinsip komunikasi terapeutik yang efektif yang sesuai dengan perspektif ilmu komunikasi maupun dalam perspektif ilmu komunikasi Islam.

Pemahaman dan penerapan prinsip-prinsip komunikasi terapeutik dan komunikasi Islam yang baik dan profesional oleh dokter dan paramedis/perawat akan dapat memberikan kepuasan pada diri pasien serta citra positif bagi rumah sakit yang bernuansa Islami.

23 Joseph A Devito, Komunikasi Antar Manusia. Terjemahan Agus Maulana. (Jakarta: Profesional Books, 1997) 
Prinsip-prinsip dasar Komunikasi Terapeutik yang perlu difahami dan diterapkan oleh dokter dan paramedis/perawat dalam memberikan pelayanan kesehatanpada setiap tahapan komunikasi terapeutik (fase orientasi, fase kerja dan fase terminasi) di rumah sakit yang bernuansa Islami adalah :

a) Adanya keterbukaan kedua belah pihak yang berkomunikasi(Openess).

b) Memiliki rasa empati(Empathy).

c) Memiliki sifat mendukung(Supportiveness).

d) Memiliki sifat positif(Positiveness).

e) Adanya kesetaraan(Equality)

Prinsip-prinsip dasar Komunikasi Islam yang perlu difahami dan di terapkan oleh dokter dan paramedis/perawat dalam menyampaikan pesan serta dalam memberikan pelayanan kepada pasien dalam setiap tahapan komunikasi terapeutik (fase orientasi, fase kerja dan fase terminasi) di rumah sakit bernuansa Islami adalah:

a) Prinsip berkata benar dan jujur ; QaulanSadida.

b) Prinsip perkataan yang efektif, berkata jelas dan tepat mengungkapkan apa yang dikehendaki ; QaulanBaligha.

c) Prinsip perkataan yang baik ; QaulanMa'rufa.

d) Prinsip perkataan yang mencerminkan kebijaksanaan dan kemulian ; Qaulan Karima.

e) Prinsip perkataan yang lemah lembut dan menyentuh hati ; QaulanLayyina.

f) Prinsip perkataan yang mudah dimengerti, yang mudah dicerna pikiran dan perasaan ; QaulanMaysura.

Devito menyatakan bahwa keterlibatan seseorang didalam sebuah peristiwa komunikasi interpersonal adalah berperan sekaligus sebagai Sumber pemberi pesan (Source) dan Penerima pesan (Receiver) serta sekaligus melakukan proses Encoder (Penyandi Pesan) dan Decorder (Penginterpretasi Pesan). ${ }^{24}$

Dokter dan paramedis/perawat sebagai komunikator melakukan peran sebagai Sumber-Penerima dan Encoder-Decorder terhadap pasien melalui

24 Joseph A Devito, Komunikasi Antar Manusia. Terjemahan Agus Maulana. (Jakarta: Profesional Books, 1997) 
bentuk-bentuk komunikasi interpersonal pada setiap tahapan komunikasi terapeutik (fase orientasi, fase kerja dan fase terminasi), yaitu ;

1. Komunikasi Verbal, komunikasi langsung dengan kata-kata yang disampaikan dengan indikator meliputi;
a) Pesan yang jelas dan ringkas.
b) Perbendaharaan kata (mudahdipahami)
c) Arti denotatif dankonotatif.
d) Pemberian jeda (selaan) dan kesempatanberbicara.
e) Waktu danRelevansi.
f) Humor.

2. Komunikasi tertulis, komunikasi dengan tulisan yang dilakukan dokter dan paramedis atau perawat seperti : penulisan nama obat pada resep, memo, penulisan surat, keterangan tentang penyakit, dan sebagainya.

3. Komunikasi Nonverbal, komunikasi yang pesannya dikemas dalam bentuk nonverbal tanpa kata-kata, meliputi:

- Penampilan Individu (SelfPerformance).

- Intonasi Suara (VoiceTone).

- Ekspresi wajah

- Sentuhan

Keberlangsungan komunikasi terapeutik pada setiap tahapan yang berpedoman pada prinsip-prinsip komunikasi Interpersonal dan juga prinsipprinsip komunikasi Islam, sebagai salah satu bagian dalam pelayanan kesehatan yang integral dan tidak terpisahkan dengan pelayanan lainnya, yang diterapkan pada rumah sakit bernuansa Islami, tentuanya akan dapat mewujudkan pelayanan kesehatan yang optimal dan bermuara pada kepuasan pasien.Kepuasan adalah perasaan senang dan puas pasien dalam memakai dan menerima pelayanan kesehatan yang diselenggarakan oleh rumah sakit yang sesuai dengan harapan pasien.

\section{Pembahasan}

Dari hasil observasi dan wawancara dengan dokter, paramedis/perawat serta pasien di rumah sakit Al Huda Genteng, menunjukkan bahwa pemahaman 
komunikasi terapeutik secara konseptual telah dipahami oleh dokter dan paramedis/perawat dan pasien di rumah sakit ini. Selain itu , prinsip-prinsip komunikasi interpersonal yang j̣uga menjadi ciri pada komunikasi terapeutik, yang menurut Devito seperti : keterbukaan (openess), empati (emphaty), sifat mendukung (supportiveness), sikap positif (positiveness) dan kesetaraan (equality) telah dilakukan walaupun secara faktual lingkup pelaksanaannya belum optimal dan merata diterapkan pada setiap fase atau tahapan komunikasi terapeutik yang dilakukan dokter dan paramedis/perawat terhadap pasien dalam pelayanan kesehatan di rumah sakit Al Huda Genteng ini. ${ }^{25}$

Hasil observasi dan wawancara dengan dokter dan paramedis/perawat di rumah sakit Al Huda Genteng ini, mendeskripsikan pemahaman yang saling menguatkan dan melengkapi tentang tujuan dan manfaat komunikasi terapeutik yang dilakukan dokter dan paramedis/perawat terhadap pasien dalam memberikan layanan kesehatan di rumah sakit tersebut.

Dari hasil observasi dan wawancara peneliti terhadap paramedis / perawat, dengan beberapa orang pasien di RS Al Huda Genteng ini bahwa pelaksanaan kegiatan yang dilakukan pada fase orientasi ketika pasien datang ke rumah sakit dan berịumpa pertama kalinya dengan dokter, paramedis/ perawat belum optimal dilakukan.

Dari hasil observasi dan wawancara dengan perawat dan pasien di Rumah Sakit Al Huda Genteng ini, komunikasi terapeutik yang dilakukan pada tahap working (kerịa) menurut peneliti telah cukup baik dilakukan. Namun kondisi komunikasi terapeutik pada fase kerịa ini belum lengkap memenuhi seluruh tindakan keperawatan yang optimal baik pada tatanan fisiologis, tatanan psikologis hingga tatanan sosioekonomi pasien. Tindakan pada fase working (keria) yang dilakukan dokter dan paramedis/perawat di rumah sakit bernuansa Islam tersebut masih pada tindakan pemenuhan kepuasan pasien pada tatanan fisiologis dan psikologis selama berada di rumah sakit saja, sedangkan idealnya sampai pada tatanan sosioekonomi seperti merujuk dan mendukung pasien ke tempat pelayanan kesehatan tertentu dan membantu pasien untuk beradaptasi dengan lingkungan baru belum dilakukan.

25 Joseph A Devito, Komunikasi Antar Manusia. Terjemahan Agus Maulana. (Jakarta: Profesional Books, 1997) 
Dari hasil wawancara dan observasi peneliti terhadap dokter, paramedic/ perawat dan pasien di rumah sakit Al Huda Genteng Banyuwangi, diperoleh temuan bahwa belum semua dokter dan paramedis atau perawat telah menerapkan prinsip-prinsip komunikasi Islam pada tahap penyelesaian (terminasi) berupa prinsip Qaulan Sadida, Qaulan Baligha, Qaulan Ma'rufa, Qaulan Karima, Qaulan Masyura maupun Qaulan Layyina. Kondisi penerapan prinsipprinsip komunikasi Islam pada tahap terminasi di rumah sakit Al Huda Genteng adalah Masih ada pasien yang berpendapat bahwa belum semua dokter dan paramedis atau perawat memberi kesempatan kepada pasien untuk memberikan tanggapan, pendapat atau menyampaikan perasaannya sehubungan dengan perkembangan atau kemajuan kesehatan pasien setelah mendapatkan asuhan medis dan asuhan keperawatan di rumahsakit.

Masih ada dokter dan perawat atau pihak rumah sakit yang belum menyimpan dokumen rekam medis (medical report) pasien dengan baik, sehingga informasi yang berhubungan dengan kondisi medis pasien akan sulit ditemukan apabila pasien tersebut ingin kembali berobat.

\section{KESIMPULAN}

Sesuai dengan penelitian yang telah dilakukan, bentuk komunikasi terapeutik yamg dilakukan dokter dan paramedis/perawat terhadap pasien rawat inap di rumah sakit Al Huda Genteng Banyuwangi baik pada tahap atau fase awal (orientasi), tahap kerịa (working) dan tahap akhir (ternimation) adalah komunikasi interpersonal melalui penyampaian pesan secara verbal, tertulis, dan non verbal. Pada fase orientasi atau tahap awal, dokter dan paramedis/perawat di rumah sakit Al Huda Genteng ini telah melakukan pelayanan kesehatan melalui komunikasi terapeutik yang memiliki tuj̣uan utama untuk merumuskan kontrak asuhan medis dan asuhan keperawatan dengan pasien, namun dari hasil observasi dan wawancara yang dilakukan oleh peneliti, diperoleh temuan bahwa ketrampilan atau kemampuan dokter dan paramedis/perawat dalam berkomunikasi dengan pasien belum optimal dan belum merata dimiliki setiap dokter dan paramedis/perawat di rumah sakit tersebut. Dokter dan paramedis/perawat pada fase awal belum semuanya mampu membina rasa percaya diri pasien dengan komunikasi terbuka, belum semuanya mampu menggali pikiran dan perasaan serta mengidentifikasi masalah pasien 
sebelum kontrak asuhan medis dan asuhan keperawatan dirumuskan. Kondisi ini terịadi karena rumah sakit Al Huda Genteng tersebut belum memiliki standart operasional prosedur yang tegas, evaluatif, dan responsif khususnya untuk pelaksanaan pelayanan komunikasi terapeutik pada fase orientasi (tahap awal) ketika pasien datang pertama kali ke rumah sakit. Sedangkan pada fase kerịa atau tahap working, dokter dan paramedis/perawat di rumah sakit Al Huda Genteng telah melakukan layanan yang dinilai cukup baik oleh pasien. Namun dari hasil observasi dan wawancara mendalam yang dilakukan peneliti, diperoleh temuan bahwa komunikasi terapeutik pada fase kerja ini masih belum lengkap sehingga belum optimal dalam memenuhi seluruh tindakan medis dan tindakan keperawatan yang optimal baik pada tatanan fisiologis dan psikologis yang hanya terbatas dapat dilihat (visibility) saj̣a seperti : pemeriksaan rutin, pemberian nutrisi serta pendampingan selama di rumah sakit, sedangkan idealnya harus sampai pada tatanan sosial ekonomi seperti : merujuk dan mendukung pasien ke tempat pelayanan kesehatan tertentu untuk mendapatkan perawatan yang lebih komprehensif dan membantu pasien untuk beradaptasi dengan lingkungan baru yang masih belum dilakukan secara optimal.Dan pada fase terminasi atau tahapakhir ketika pasien diperbolehkan pulang kerumah, dokter dan paramedis/perawat di rumah sakit Al Huda Genteng ini belum sepenuhnya melakukan tahapan yang idealnya harus dilakukan seperti : kegiatan evaluasi subyektif (pasien diberi kesempatan untuk memberi pendapatnya tentang kepuasannya terhadap layanan asuhan keperawatan) dan kegiatan evaluasi obyektif (pasien diberi kesempatan untuk memberi pendapat tentang kepuasannya terhadap kemajuan kesehatannya setelah mendapatkan pengobatan). Kondisi ini terịadi karena di rumah sakit Al Huda Genteng ini belum memiliki standar operasional, prosedur yang tegas, evaluatif dan responsif khususnya untuk pelaksanaan pelayanan komunikasi terapeutik pada fase terminasi (tahap akhir) ketika pasien diperbolehkan pulang kembali ke rumahnya.

Penerapan prinsip-prinsip komunikasi Islam dalam penyampaian pesan seperti : Qoulan Sadida (pembicaraan yang benar dan j̣ụur), Qoulan Baligha (pembicaraan yang efektif), Qoulan Ma'rufa (pembicaraan yang baik dan menentramkan),QoulanKarima(pembicaraan yang baik dan mencerminkan kemuliaan), Qoulan Layyina (pembicaraan yang lemah lembut), Qoulan Maysura(pembicaraan yang ringan dan mudah dimengerti) belum sepenuhnya 
dilakukan dan dijadikan pedoman oleh dokter dan paramedis/perawat dalam memberikan pelayanan kesehatan terhadap pasien. Dari hasil observasi dan wawancara yang mendalam yang dilakukan oleh peneliti diperoleh temuan bahwa masih terdapat kondisi, dimana dokter maupun paramedis/perawat tidak mengucapkan salam, berkomunikasi dengan wajah yang datar atau tidak memberikan senyum, memberikan informasi medis yang kurang jelas karena terlalu cepat dalam menjelaskan, masih ada dokter dan paramedis/perawat yang berbicara seadanya dan kurang menunjukkan penerimaan yang ramah serta tulus terhadap pasien.

Model komunikasi dokter dan paramedis/perawat terhadap kepuasan pasien dalam pelayanan kesehatan di rumah sakit Al Huda Genteng yang direkomendasikan dalam penelitian ini adalah model komunikasi terapeutik yang berlandaskan prinsipprinsip komunikasi Islam yaitu :Qoulan Sadida, Qoulan Baligha, Qoulan Ma'rufa, Qoulan Karima, Qoulan Layyina, Qoulan Maysura pada seluruh kegiatan komunikasi terapeutik baik pada fase orientasi atau tahap awal, fase kerịa atau tahap working, dan pada tahap terminasi atau fase akhir.

\section{DAFTAR PUSTAKA}

Arwani, 1999. Komunikasi Dalam Keperawatan. Jakarta:Buku Kedokteran EGC. Beekun, Rafik Issa, 2004. Etika Bisnis Islam. Yogyakarta :Pustaka Pelajar.

Budyatna Muhammad dan Ganiem Leila Mona, 2011. Teori Komunikasi Antar Pribadi.Jakarta :Prenada Media Group.

Bungin Burhan, 2003. Analisis Data Penelitian Kualitatif.Jakarta :PT Grafindo Perkasa.

Cangara, Haffied, 1998. Pengantar Ilmu Komunikasi, Jakarta : Raja Grafindo Perkasa.

Damayanti, Mukhripah, 2008. Komunikasi Terapeutik Dalam Praktik Keperawatan. Bandung:Rafika Aditama.

Devito, Joseph A. 1997. Komunikasi Antar Manusia. Terjemahan Agus Maulana. Jakarta:Profesional Books.

Effendy, Onong Uchjana.2003. Ilmu, Teori dan Filsafat Komunikasi. Bandung :PT.Remaja Rosdakarya.

Fitriyani, Rohmah. 2016. Etika Komunikasi Dalam Perspektif Islam, Sumber : https://www.academia.edu/11167050/Etika 
Komunikasi_Dalam_Perspektif_Islam, diakses pada tanggal 20 November 2018.

Hefni, Hardjani. 2015. Komunikasi Islam, Jakarta : Prenadamedia Group.

Jacobalis, S. 1995. Liberalisasi Bisnis Jasa Kesehatan dan Dampaknya Bagi Rumah Sakit Indonesia, Jakarta : IRSJAM XXXVII.

Kholil, Syukur, 2007. Komunikasi Islami,Bandung :Cita Pustaka Media.

Kotler,Philip,2003.Marketing Management, $11^{\text {th }}$ New Jersey : Prentice Hall,Inc.diIndonesiakan oleh Ancella Aniwati Hermawan, Manajemen Pemasaran : Analisis, Perencanaan, Implementasi dan Pengendalian. Jakarta : Salemba Empat.

Komalasari, Veronica, 2002. Peranan Informed Consent Dalam Transaksi Terapeutik. Bandung:PT. Citra Aditya Bakti.

Lamsudin, Rusdi ,2002. Nuansa Pelayanan Kesehatan yang Islami di Rumah Sakit Islam. Yogyakarta : Suara Muhammadiyah, Edisi 02.

Machfoedz, Mahmud,2009. Komunikasi Keperawatan (Komunikasi Terapeutik), Yogyakarta : Ganbika.

Mafri, Amir, 1999. Etika Komunikasi Massa Dalam Pandangan Islam. Jakarta : Logos. McGuire, Meredith B., 2002. The Social ContexFifth Edition. California:Wadsworth Publishing Company.

Muis, A., 2001. Komunikasi Islami. Bandung : Remaja Rosda Karya.

Mulyana, Dedy, 2001. Ilmu Komunikasi Sebuah Pengantar.Bandung :PT. Remaja Rosda Karya.

Neuman W. Lawrence, 2003. Social Research Methods Qualitative And Quantitative Approaches. Boston ;Pearson Education, Inc.

Nursalam,2011. Manajemen Keperawatan. Edisi 3,Jakarta : Erlangga.

Poerwandari, Kristi E., 1998. Metode Penelitian Sosial. Jakarta :Universitas Terbuka.

Priyanto, Agus, 2009. Komunikasi dan Konseling Aplikasi Dalam Sarana Pelayanan Kesehatan Untuk Perawat dan Bidan . Jakarta:Salemba Medika.

Purba, Jeny Marlindawani, Komunikasi Dalam Keperawatan, Sumber :http://library.usu.ac.id/download/fk/keperawatan-jenny.pdf, diakses tanggal 19 November 2018.

Purwanto, Hery, 1994. Komunikasi Untuk Perawat. Jakarta : EGC. 
Rakhmat, Jalaluddin.2001. Psikologi Komunikasi. Bandung : Penerbit PT. Remaja Rosda Karya.

Sinaulan, Ramlani Lina. 2016. Komunikasi Terapeutik Dalam Perspektif Islam. Jurnal Komunikasi Islam, Volume 06, Nomor 01, Juni 2016. Prodi KPI Fak Dakwah IAIN Sunan Ampel Surabaya- Asosiasi Profesi Dakwah Islam Indonesia.

Saefullah Ujang, 2007. Kapita Selekta Komunikasi Pendekatan Budaya dan Agama. Bandung : Simbiosa Rekatama Media.

Sheldon Lisa Kennedy ,2010 Komunikasi Untuk Keperawatan Erlangga. Jakarta. Smet, Bart, 1994. Psikologi Kesehatan. Jakarta :Penerbit PT. Grasindo.

Sugiyono, 2012. Metode Penelitian Pendidikan Kuantitatif, Kualitatif $R$ \& D.Yogyakarta : Pustaka Pelajar.

Suryani, 2005. Komunikasi Terapeutik Teori Dan Praktek. EGC. Jakarta. Tamsuri, Anas, 2005. Buku Saku Komunikasi Dalam Keperawatan. EGC. Jakarta. Tjiptono, Fandy, 1995. Manajemen Jasa. Jakarta : Andi Press.

Saefullah Ujang, 2007. Kapita Selekta Komunikasi Pendekatan Budaya dan Agama. Bandung : Simbiosa Rekatama Media.

Suryani, 2005. Komunikasi Terapeutik Teori Dan Praktek. EGC. Jakarta. Tamsuri, Anas, 2005. Buku Saku Komunikasi Dalam Keperawatan. EGC. Jakarta.

Tamsuri, Anas, 2005 .Buku Saku Komunikasi Dalam Keperawatan. EGC. Jakarta

Thoha, M.2002. Perilaku Organisasi, Jakarta : Raja Grafindo Persada.

Tjiptono, F.2000. Strategi Pemasaran, Yogyakarta : Andi Offset.

Widjaja, HAW., 2000. Ilmu Komunikasi : Pengantar Studi. Rineka Cipta. Jakarta. Wijaya Dkk., 1996. Komunikasi Terapeutik. Jakarta :Akademi Kesehatan Gigi Depkes RI. 